\title{
PROJECT CITIZEN: DEVELOPMENT OF SOCIAL SKILLS AND UNDERSTANDING OF CONTEMPORARY ISSUES (STUDY AT AHMAD DAHLAN UNIVERSITY)
}

\author{
Nufikha Ulfah ${ }^{1}$, Yayuk Hidayah ${ }^{2}$, Mirza Hardian ${ }^{3}$, Meiwatizal Trihastuti ${ }^{4}$ \\ ${ }^{1}$ Temporary Lecturer at Ahmad Dahlan University, ${ }^{2}$ Primary School Department, Ahmad Dahlan University, \\ ${ }^{3}$ Department of Citizenship Education, University of Riau, \\ ${ }^{4}$ Department of Citizenship Education, High School of Teacher Training and Education (STKIP) Pasundan \\ 1,2Jl. Kapas 9, Semaki, Umbulharjo, Yogyakarta, Indonesia, \\ ${ }^{3}$ Kampus Bina Widya Km 12,5 Simpang Baru Pekanbaru, Indonesia, ${ }^{4}$ Jl. Permana 32 B Cimahi, Indonesia \\ Email: ulfahnufikha@gmail.com¹, yayuk.hidayah@pgsd.uad.ac.id ${ }^{2}$, mirzahardian@gmail.com³ \\ meiwatizal@yahoo.co.id ${ }^{4}$
}

\begin{abstract}
:
In a cluster of social science, Citizenship Education has a role in developing social skills and become a media of preparing smart and thoughtful citizen towards citizenship issues, and it also gives alternative solution for a particular problem. This study aimed to describe the students' social skills and contemporary issue understanding through Project Citizen-Based Learning in Citizenship Education as a part of General Compulsory Courses (MKWU). This research used descriptive qualitative method which took place at Ahmad Dahlan University. This research indicated that the steps of Project Citizen could develop the students' social skills and contemporary issue understanding. The development of social learning through Citizen Project-based learning model in Citizenship Education as MKWU was carried out through cooperation, mutual assistance, communication, and responsibility. The understanding of contemporary issues was carried out through the principles of Project Citizen which included; (1) possession of soft-skill communication in doing task/project, (2) ability to manage time for completing task/project, and (3) interaction with technology in completing project.
\end{abstract}

\begin{abstract}
Abstrak:
Dalam rumpun ilmu sosial, Pendidikan Kewarganegaraan memiliki peran dalam mengembangkan keterampilan sosial, dan menjadi wahana dalam mepersiapkan warga negara yang cerdas dan peka terhadap isu-isu kewarganegaran serta mampu memberikan solusi alternatif terhadap suatu permasalahan. Penelitian ini bertujuan untuk pengembangan keterampilan sosial dan pemahaman isu kekinian mahasiswa melalui model pembelajaran berbasis Project Citizen pada MKWU Pendidikan Kewarganegaraan. Penelitian ini menggunakan metode kualitatif deskriptif yang berlokasi di Universitas Ahmad Dahlan Yogyakarta. Hasil penelitian menunjukan bahwa langkah-langkah Project Citizen dapat mengembangkan keterampilan sosial dan pemahaman isu kekinian mahasiswa. Pengembangan keterampilan sosial melalui model pembelajaran berbasis Project Citizen pada MKWU Pendidikan Kewarganegaraan meliputi kerjasama, gotong royong, berkomunikasi dan bertanggung jawab. Sementara itu, pemahaman terhadap isu kekinian dilakukan melalui prinsip Project Citizen yang meliputi (1) kepemilikan soft-skill berkomunikasi saat mengerjakan tugas, (2) kemamuan mengatur waktu dalam menyelesaikan tugas, dan (3) interaksi dengan teknologi dalam penyelesian tugas.
\end{abstract}

Keywords:

Citizenship Issue, Citizenship Education, Social Skill 
How to Cite: Ulfah, N., Hidayah, Y., Hardian, M., \& Trihastuti, M. (2020). Project Citizen: Development of Social Skills and Understanding of Contemporary Issues (Study at Ahmad Dahlan University). Lentera Pendidikan : Jurnal Ilmu Tarbiyah dan Keguruan, 23(1), 9-21. https://doi.org/10.24252/lp.2020v23n1i2.

\section{INTRODUCTION}

Citizenship Education is part of the national education. The field of Civic Education has associated closely with Pancasila as the goal of Citizenship Education in Indonesia. In the Content Standard for Primary and Secondary Education (2006), Citizenship Education is seen as a subject that focuses on the formation of citizens who do not only understand but also being able to implement the rights and obligations to be a smart, skilled, and civilized citizen as mandated by Pancasila and Constitution 1945.

During its implementation, the policy of Pancasila and Citizenship Education (PPKn) curriculum undergoes a change, and it also has an impact on the use of term and material substances. In Article 35 paragraph (5) of Law No. 12 in 2012, Citizenship Education which was originally packaged in one subject, namely Pancasila and Citizenship Education which is now split into two entities, namely Pancasila and the Citizenship (Somantri \& Winataputra, 2017). These courses are part of the compulsory subjects in several universities (state and private universities) in Indonesia as mandated in Article 35 paragraph (5) No. 12 year 2012.

The dimension of Pancasila as a course subject is philosophic and ideological by carrying out a psycho-pedagogic and andragogy mission to develop the competencies of citizens, while the Education Citizenship carry out the psychological and pedagogical mission to develop citizenship intelligence. In this case, Bronson (1999) calls civic intelligence as knowledge of citizenship that relates to substances of citizenship. Thus, the substance and teaching of Pancasila and the Education Citizenship is mutually inspiring and strengthening one another. In the context of Indonesia, Civic is substantively and pedagogically designed to develop well-established citizen's intelligence in any level of education. At the present time, this field becomes an inherent part of the instrumentation and national educational praxis within five status, one of those as a subject in college (Winataputra \& Budimansyah, 2007). Relevant to this evidence, Bronson (1999) argues that Citizenship education has a goal to form students to be smart and good citizens based on three principle components, namely civic knowledge, civic skills, and civic dispositions (Winarno, 2014).

In addition, Citizenship Education should also focus on skills that are required in creating a civil society accountable, effective, and scientific in the political process, such as interacting, monitoring, and influencing. Interacting regards to skills or capabilities of citizens to communicate and cooperate with others, to build coalitions, and to manage conflicts in peaceful and honest ways. Meanwhile, monitoring acts as a surveillance function. These include participatory skills in terms of affecting political processes (formal and informal) and governance (Branson, 1999). Department of National Education (2006) describes the learning goals of Citizenship Education is to provide the ability for citizens 
to be able to think critically, rationally, and creatively in responding to the issue of citizenship, to participate intelligently and act intelligently in the activities of society, nation and state (Ulfah, 2017).

Based on these descriptions, in a relationship with the community, social skill is necessary. Lasmawan quoted by Antayani (2016: 5), explains "social skill is an ability that aims to establish and develop the character of students as social-cultural beings...". Social skill is closely related to the abilities to adapt, communicate, and participate in the life of local communities by developing a sense of responsibility, trust, capable to think critically, and solve problems or addressing the realities of social and contemporary issues (Maryani \& Syamsudin, 2009).

Pancasila and Citizenship Education as General Compulsory Courses (MKWU) in Ahmad Dahlan University (UAD) Yogyakarta regard to the students' abilities or skills, still under develop social skill, when it is viewed from the way of the students communicate and cooperate with their friends in their group tasks. Although in group discussion, students are still unable to carry out the discussion effectively and tend to individual discuss. The preliminary investigation has proven that there is a natural aspect of individualism in students' personalities. Evidently, they are not encouraged to share assignments, and this evidence implies that they do not have communication skills.

In the lecturing process, communication skills become important for the success and achievement of learning goals. According to the Standard Competency of Graduates (SNDIKTI), Attitude at point (6) involves cooperation, has social empathy, and cares for society and environment. This stipulation is also based on Standard Competency of Graduates (SNDIKTI) on General Skill at level 6 Undergraduate (Nurwardani, Saksama, Winataputra, Budimansyah, Sapriya, Winarno, Mulyono, Prawatyani, Anwar, Evawany, Priyautama, \& Festanto, 2016). Based on this evidence, this Graduate Competency Standard is considered as a cornerstone in the development of learning outcomes for each course, especially Citizenship Education that factually can comprehensively develop students' abilities in the term of knowledge, attitudes, and skills.

Regarding the communication skill as one of matters in the discourse of social skill, Muijs \& Reynolds (2008) clarifies that the impact of the lack of social skill is the students' low academic achievement. Besides, they also tend to be lonely and have low self-esteem. Ironically, they can drop out of school. In this case, Gresham in Bremer \& Smith (2004) reemphasize five dimensions of social skills, namely: (1) the skill to relate to others (peerrelational skill); (2) self-management skill; (3) academic skill; (4) skill to comply with rules and (5) the skill of expression. These five dimensions need to be trained in teaching and learning activities to prepare students to become part of the community and take a part in it.

Advances in technology and science have impact on educational world. Educational actors cannot let go of the fact that technological advances lead to a world without borders or globalization. According to Held \& Mcgrew (2002), globalization is an expansionary scale that is growing fast across continents. It provides space for humans to be able to dissolve in the negative or positive impacts. Because globalization has two blades on the 
positive or the negative sides, in the world of education, especially Citizenship Education (PKn) learning patterns as part of MKI/MKU (Primary Courses or General Courses) continue to be sought to adjust the developing times, one of them through Project Citizen.

In the context of Citizenship Education either as primary course or general course, the learning pattern is adjusted with developing era and this effort is still pursued, especially through 'Project Citizen'. Learning-based citizen project in Pancasila and Citizenship Education (PPKn) either as primary course or general course is a portfoliobased learning. Project Citizen is a collection of students' works that are beneficial and optimally integrated (Budimansyah, 2009). Through Project Citizen, students are able to understand more about the concept and knowledge as well as the practical aspect of particular knowledge. Project Citizen implies a work cooperatively, this way makes the students active. The existence of cooperative works for students can develop and practice their social skill, and the Project Citizen can increase students' understanding of contemporary issues, specifically in the Citizenship Education.

Several previous researchers had studied Project Citizen. The first study was a qualitative research with case study approach that purposed to explore Project Citizen learning model to equip students in gaining a fun learning environment, providing experience, and enhancing students' knowledge. It had addressed an indication that the learning model of Project Citizen applied the development and the progress of information and technology to support maximum learning outcomes in accordance with current development (Adha, Ulpa, Yanzi, Nurmalisa, Hidayat, \& Putri, 2000). Besides, a research that acknowledged the lack of critical thinking skills of Citizenship Education at the Fifth grade students in elementary school, indicated that the students' critical thinking skills and learning outcomes increased after implementing Project Citizen model. In the first cycle, the average value of the students' critical thinking skills was 58.71, the second cycle was 72.19 , and the third cycle was 91.76 . Then, the average of the students' learning outcomes reached 48.83 in the first cycle, the second cycle reached 64.59 , and the third cycle reached 80 (Ulfah \& Hamid, 2017).

On the other hand, a research on the implementation of Project Citizen model on Citizenship Education learning as a character strengthening of students at SMAN 9 Bandung, had indicated several findings, namely: 1) the formulation of Project Citizen learning was carried out through syllabus and Learning Plans (RPP); 2) the implementation of Project Citizen was fair and made students active; 3) time and cost were evidently the problems in the implementation of Project Citizen; 4) strategies to minimize the obstacles had been encountered - one of them was by cooperation of all parties; and 5) tendency of students' character strengthening after following Project Citizen (Sopianingsih, 2016).

Another research was the influence of Problem-based Learning (PBL) and Project Citizen in teaching Citizenship Education toward the students' critical thinking skills and their discipline at SMK Diponegoro Depok Sleman. This research had shown several findings, namely: (1) there was a significant effect on Problem-based Learning model and Project Citizen to the students' critical thinking skills in teaching Citizenship Education; (2) 
there was a significant effect on Problem-based Learning model and Project Citizen to the students' discipline in teaching Civic Education; and (3) there was a significant effect on Problem-based Learning model and Project Citizen to the students' critical thinking ability and discipline code in teaching Civic Education (Marzuki \& Basariah, 2017). Thus, the study on learning innovation by using Project Citizen, asserted that Project Citizen provided an opportunity for learners to take a part as citizens by practicing cooperation, negotiation, debate, and dialogue (Budimansyah, 2009).

Based on the previous studies, it was understood that the Project Citizen-based learning model can bring in various benefits for learners. Therefore, this study would like to formulate a research problem as "How was the application of Project Citizen to develop social skills and increase students' understanding of contemporary issues?" This study was theoretically expected to be benefit for students in giving any contribution to improve the quality of understanding of contemporary issues. Meanwhile, it was practically expected that this study would be beneficial for reference and further recommendation for further writers to explore and conduct an experiment in using learning models of Citizenship Education.

\section{RESEARCH METHOD}

The method used in this study was qualitative description which obtained textual data in accordance with the observed phenomena (Moleong, 2011). This study aimed to describe the students' social skills and contemporary issue understanding through Project Citizen-based Learning model in Citizenship Education as a part of MKWU (General Compulsory Courses). The research was conducted in Ahmaad Dahlan University Yogyakarta. The subjects were the students of Communication Sciences Department in Academic Year 2019/2020. The data were collected through observation and documentation. The data was then analyzed by using Milles \& Huberman (1992) model which consisted of data collection, data reduction, data display, and conclusion.

\section{RESULTS AND DISCUSSION}

Based on the results of this study, the researcher would like to highlight and focus into two primary discussions, namely: (1) the use of Project Citizen-Based Learning model; and (2) the development of social skills and the increase of students' understanding of contemporary issues.

\section{The Use of Project Citizen-based Learning Model}

Learning is a relatively permanent change process occurred in potential behaviour as a result of experience (Anderson, 2000). Gagne and Briggs define learning as a model that is designed to influence learners in a learning process to get any change (Department of National Education, 2004). Learning is not confined to the activities carried out with only focusing on teachers, but it rather becomes a media and strategy that is developed to activate learners' concentration in exploring knowledge and learning experience. Thus, this phenomenon of learning can emerge a terminology called Teacher-Centre Approach and Student-Centre Approach (Winarno, 2014). 
Citizenship Education is pedagogic-ideological and socio-cultural media, and accepted as human civilization development. It also functions as the development of civic competencies that consists of civic knowledge, civic dispositions, civic skills, civic competence, civic confidence, civic commitment that internally head to integrative competence called "well informed and reasoned decision making" (Somantri \& Winataputra, 2017). Based on this description, the learning of Citizenship Education in every level of education does not only emphasize cognitive aspect, but also the development of prospective competencies to be a good and smart citizen.

Somantri \& Winataputra (2017) strengthen that learning of Citizenship Education is developed in the context of educational philosophy and eclectically exploits discipline, cognitive, Gestalt/Fields theories or starting from Expository approach to inquiry approach. These theories become the basis for teachers' and lecturers' roles as "director of learning" which is expected to act as scientist, well-informed, and well-dedicated. Therefore, teachers and lecturers of Citizenship Education are demanded to develop and improve professional and pedagogic competences. Intrinsically, the learning of Citizenship Education in general adopts epistemology and students' integrative potential development method (Somantri \& Winataputra, 2017).

There are various models of the students' Competency-Based Learning; two of them are Problem-Based Learning and Project-Based Learning. Both models develop the students' social competence and critical thinking skill (Winarno, 2014). At present time, there are number of developing learning models with a new nomenclature adapted and adopted from research approach (Inquiry Approach), which comes from the idea of John Dewey's syntagmatic (1910), such as Problem Solving, Project, Problem-Based Learning, Group Investigation, Social Inquiry, and so on. These models -philosophically, academically, and pedagogically- are intended to be the media to develop learners' abilities (Somantri \& Winataputra, 2017). The Problem-Based Learning is inter-related with Project-Based Learning because both of the learning models emphasize active students' environment, teamwork, and authentic or meaningful evaluation techniques.

In Citizenship Education, the civic skill consists of two subs, namely intellectual skill which cannot be separated from civic knowledge, and participatory skill. In this study, the intellectual skill focuses on critical thinking ability in comprehending and responds the recent issues, especially citizenship issues. Meanwhile, participatory skill (social skill) focuses on the abilities to cooperate in a group, to interact in-pairs, to join in a group, to have new friendship, to handle a conflict, and to learn collaboration. Mini Project Citizen is one of learning models and methods that can be used to develop citizenship skill. This model is adopted from Project Citizen learning model. There are some steps to implement the Mini Citizens Project as follows.

\section{Identifying Problems (Time: 1 Week)}

Each student identifies problems that arise in real life in the community. For example, people who perform a bad treat in traffic, littering, throwing rubbish randomly, disrespectful behavior, abuse of authority, and so on. Making a list of issues from problems that have been identified. 
Table 1. The Sample List of Problems

\begin{tabular}{|c|c|c|}
\hline No. & Scope of Problem & Attitude and Behavior Character \\
\hline \multirow[t]{6}{*}{1.} & \multirow[t]{6}{*}{ Injustice } & - Not to follow the rules (unfair). \\
\hline & & $\begin{array}{l}\text { - Not to respect others. For example, when a speaker } \\
\text { delivers his/her speech, the audiences are freely talking, } \\
\text { operating their smartphones, and so on. }\end{array}$ \\
\hline & & $\begin{array}{l}\text { - Not to respect self, such as being not interested in } \\
\text { reading books. }\end{array}$ \\
\hline & & $\begin{array}{l}\text { - Irresponsible, such as ignoring a duty anyway, and } \\
\text { transferring his/her responsibility to others. }\end{array}$ \\
\hline & & $\begin{array}{l}\text { - Dishonest. For example, manipulating data/facts, and } \\
\text { cheating on tests. }\end{array}$ \\
\hline & & - No manners. For example, speaking roughly, and so on. \\
\hline \multirow[t]{7}{*}{2.} & \multirow[t]{7}{*}{ Have no love } & $\begin{array}{l}\text { - No loyalty or allegiance to the nation, the state, and } \\
\text { others. }\end{array}$ \\
\hline & & - No soul of patriotism. \\
\hline & & - Not to help others. \\
\hline & & - Stingy and not ungenerous. \\
\hline & & - $\quad$ No empathize with others. \\
\hline & & - Have no compassion. \\
\hline & & - Bad-behaved, vindictive, and have no forgiving spirit. \\
\hline
\end{tabular}

Note: To deepen the existing problems, students may interview their parents or neighbor.

\section{Choosing Problems to Observe (Time: 1 Week)}

From the problems that have been identified, each group chooses a problem to investigate. In determining and deciding the prospective problem, each group can conduct a discussion or by voting.

\section{Collecting Data and Information (Time: 2 weeks)}

Before investigating, each group should determine the sources of information. Make a team of research that has a responsibility to observe the data and information to each of data source. Do not forget to record in a document during the investigation/observation.

\section{Generating Reports of Mini Project Citizen (Time: 1 Week)}

The reports of Mini Project Citizen can be illustrated in the following table.

Table 2. Report Format of Mini Project Citizen

\begin{tabular}{ll}
\hline \multicolumn{1}{c}{ Parts } & \multicolumn{1}{c}{ To do List } \\
\hline & (a) $\begin{array}{l}\text { Explain the selected problems that have } \\
\text { been observed. }\end{array}$ \\
1. Describing problem & (b) $\begin{array}{l}\text { Explain the reason for the problem, and } \\
\text { emphasize the audiences why this problem } \\
\text { is crucial to observe. }\end{array}$ \\
\hline
\end{tabular}




\begin{tabular}{|c|c|c|}
\hline 2. & $\begin{array}{l}\text { Assessing alternative policy as } \\
\text { recommendation to solve } \\
\text { problems }\end{array}$ & $\begin{array}{l}\text { Explain the alternative policies made to } \\
\text { overcome the problems. }\end{array}$ \\
\hline 3. & Developing public policy group & $\begin{array}{l}\text { Improvise and explain a particular policy that } \\
\text { has been agreed and supported by the group } \\
\text { to overcome the problem. }\end{array}$ \\
\hline 4. & Developing an action plan & $\begin{array}{l}\text { Improvise a particular planning that presents } \\
\text { how citizens can influence government to } \\
\text { accept the supported policy. }\end{array}$ \\
\hline 5. & Appendixes & $\begin{array}{l}\text { Attach well-established supplementary } \\
\text { materials from documentation to be used for } \\
\text { research/observation verification. For } \\
\text { example, the written statements, list of } \\
\text { information sources, map, graphic image, } \\
\text { picture, authentic literature, and so on. }\end{array}$ \\
\hline 6. & Performance table & $\begin{array}{l}\text { Make a table of working that contains job } \\
\text { division of each person in a group. }\end{array}$ \\
\hline
\end{tabular}

\section{Presenting the Report of Mini Project Citizen}

The presentation is carried out by a representative of each group (4-5 people) and performed it one after another. Each group is compulsory to make slides of PowerPoint that contains general ideas of group's report.

\section{The Development of Social Skill and Contemporary Issue Understanding}

The development of social skill through Project Citizen-Based Learning in Citizenship Education as a part of General Compulsory Courses (MKWU) is expected to give a benefit in handling a paradox in interaction faced by students. In this case, the development of social skill is synchronized with the benefits of Citizenship Education; that is to form character. The Citizenship Education in college is one of compulsory courses that form students' character (Trisiana \& Wartoyo, 2016). There are some matters in the model of Project Citizen-Based Learning in Citizenship Education that (factually) can develop and improvise students' social skill, namely: 1) proposing questions openly; 2) encouraging a bravery in speaking; 3) carrying out good etiquette in giving argumentation; and 4) being up-to-date and literacy on recent information. As response to these matters, the enthusiastic citizen is important, and that a tight social skill is also important in a state context (van Steden, van Caem, \& Boutellier 2011). Through a model of Project CitizenBased Learning in teaching Citizenship Education, the students' social skill can increase and they can be well-behaved in future.

The activities within Project Citizen-Based Learning in Citizenship Education as a part of General Compulsory Courses (MKWU) has given feedback in growing up the students' skill which is relevant to the scope of learning targets. Through Project CitizenBased Learning in teaching Citizenship Education, the students' social skill (as social being) can be developed through cooperation and mutual assistance. These manners can also develop critical thinking skill. 
A finding on the skill depelopment in Project Citizen-Based Learning in Citizenship Education as a part of General Compulsory Courses (MKWU), is supported by the result of a survey in 2014 on 144 respondents that are involved in various projects by the Netherlands' KPS. The result of the survey indicates that although the mutual-trust relationship among the actors in increasing the participation of publics, the presence of contract that enables any flexibility has caused an increase in the participation of citizen (Nederhand \& Klijn, 2016). Through this finding, the implementation of Project CitizenBased Learning in teaching Citizenship Education, the existence of consensus or agreement in a project completion, has become an accurate media for members of group in obtaining solidarity among others.

The social skill through Project Citizen-Based Learning in Citizenship Education as a part of General Compulsory Courses (MKWU), contains various aspects that can be developed in interacting with others. Prabowo \& Faridah (2013) affirms that social skill involves a cooperation and communication. 'Cooperation' has two indicators, namely: being charitable in mutual assistance and appreciating responsibility. On the other hand, 'communication' is characterized by some indicators, namely: ability in listening, delivering argument, and having competence in communication and technology. This finding is also supported by a research that explores on how international higher educational experts conceptualize 'global citizen' and 'globally ideal graduates'. The terminology 'globally ideal graduates' becomes ambiguous, and that the 'global citizen' can be tolerated (Lilley, Barker, \& Harris, 2016). In Project Citizen-Based Learning in teaching Citizenship Education, social skill can be developed and improvised, and the ideal graduates' will be optimally gained.

The improvisation of contemporary issue understanding on the students through Project Citizen-Based Learning in Citizenship Education as a part of General Compulsory Courses (MKWU) can improvise and increase identification on local, national, and international problems. Social knowledge is a process that purposes to involve publics in scientific project through systematic data collection (Jiang, Zhang, \& Jing, 2019). In the concept of Project Citizen in teaching Citizenship Education, the students can collaboratively design a relevant solution based on the learning approach that has been carried out. Through Project Citizen-Based Learning in teaching Citizenship Education, the improvisation of contemporary issues can improvise and increase the quality of human resource.

In Project Citizen-Based learning to teach Citizenship Education as a part of General Compulsory Courses (MKWU), there are three things that can improvise and increase the students' contemporary issue understanding, namely: (1) the possession of soft-skill communication in doing a project, and (2) ability to manage time for completing task/project, and (3) interaction with technology in completing project. Relevant to this case, social media has a great potency as crucial aspect in human lives (Li, Yang, Zhang, \& Zhang, 2019). The existence of diversity in the improvisation of contemporary issue on 
students through Project Citizen-Based Learning of Citizenship Education, has become an indication that today's learning should be able to respond challenges in various educational demands of publics.

Project Citizen-Based Learning to teach Citizenship Education as a part of General Compulsory Courses (MKWU) focuses on current topics. The current topics are supposed to encourage students' participation in it, because the success of a learning depends on the approach used to execute it (Hidayah, Ulfah, \& Suyitno, 2019). By Project Citizen-Based learning to teach Citizenship Education, the contemporary issues can be processed by the students. The use of the contemporary issues as learning topics of Citizenship Education is expected to produce any solution that still holds Indonesia's local wisdom.

Finally, the contemporary issues on the students through Project Citizen-Based Learning in teaching Citizenship Education as a part of General Compulsory Courses (MKWU) depend on the achievement capability of potential group's project productivity. The factors that promote the participation of citizen has produced and encouraged an interest in public's viewpoint (Ripat, Redmond, \& Grabowecky, 2010). The representation of current issues on students through Project Citizen-Based Learning has become an ideal idea in responding today's national problem, such as cultural pluralism that has given a historical track on the existence and urgency of rights (Miller, 2015). Meanwhile, the form of citizenship has given a particular mark for citizen. Various issues have spread extensively, and these do not only include particular agenda, but also social, politics, economy, education, and others. This polemic is expected to stimulate the development of understanding on contemporary issues to the students through Project Citizen-Based Learning of Citizenship Education.

\section{CONCLUSION}

Based on the findings and discussion, it can be concluded that the development of the students' social skills and understanding on contemporary issues through Project Citizen-Based Learning in teaching Citizenship Education as a part of General Compulsory Courses (MKWU) involves several steps, namely: 1) Mini Project Citizen; identifying problem, selecting problem that is going to be studied, collecting data and information, and presenting the result of Mini Project Citizen, 2) Project Citizen; cooperating, mutual assistance, communicating, and being responsible. The students' understanding of contemporary issues is carried out through Project Citizen which involves: (1) the possession of soft-skill communication in doing a project, and (2) ability to manage time for completing task/project, and (3) interaction with technology in completing project that relates to the contemporary issues. Particularly, this study gives a recommendation for further researchers to be able to improvise Project Citizen extensively of General Compulsory Courses in a variety of students' learning outcomes. 


\section{REFERENCES}

Adha, M. M., Ulpa, E. P., Yanzi, H., Nurmalisa, Y., Hidayat, O. T., \& Putri, D. S. (2000). Relevansi Pembelajaran Project Citizen "Memproduksi" Pengetahuan Dan Keterampilan Pembelajar Masa Kini Dan Masa Depan. Paper presented at Seminar Nasional Pendidikan Fakultas Keguruan dan Ilmu Pendidikan, Universitas Lampung. http://repository.lppm.unila.ac.id/13307/1/Semnas\%20FKIP\%20UNILA\%20M. $\% 20$ Mona\%20Adha.pdf.

Anderson, L. W., Krathwohl, D. R., Airasian, P. W., Cruikshank, K. A., Mayer, R. E, Pintrich, P.R., Raths, J., \& Wittrock, M. C. (2000). A Taxonomy for Learning, Teaching, and Assesing (A Revision of Bloom's Taxonomy of Educational Objectives, Abridged Edition). Longman: Pearson.

Antayani, K. D. (2016). Penerapan Model Pembelajaran Kooperatif Tipe Think Pair Share untuk Meningkatkan Keterampilan Sosial dan Hasil Belajar PPKn Siswa Kelas XI MIPA 2 di SMA Negeri 2 Singaraja. Jurnal Pendidikan Kewarganegaraan, Vol 4, No.(1), 1-8. https://doi.org/http://dx.doi.org/ 10.23887/jpku.v4i1.20841.

Branson, M. S. (1999). Belajar "Civic Education" dari Amerika. Yogyakarta: LKiS.

Bremer, C. \& Smith, J. (2004). Teaching Social Skill. National Center on Secondary Education and Transition Information Brief, $3(5), \quad 1-5$. http://www.ncset.org/publications/info/NCSETInfoBrief_3.5.pdf.

Bronson, M. S. (1999). Belajar Civic Education Dari Amerika. Yogyakarta: LKiS.

Budimansyah, D. (2009). Inovasi Pembelajaran “Project Citizen.” ABMAS Media Komunikasi dan Informasi Pengabdian Kepada Masyarakat. http://jurnal.upi.edu/abmas/ view/407/inovasi-pembelajaran--"project-citizen".html.

Held, D., \& McGrew, A. (2002). Globalization/Anti-globalization. Malden, MA: Blackwell Publishers.

Hidayah, Y., Ulfah N., Suyitno, S. (2019). Analisis Pendekatan Pembelajaran Mata Kuliah Wajib Umum Pancasila dan Pendidikan Kewarganegaraan di Perguruan Tinggi. JPK: Jurnal Pancasila dan Kewarganegaraan, 4(1), 22-33. https://doi.org/10.24269/jpk.v4.n1.2019.pp22-33.

Jiang, N., Zhang, L., \& Jing, C. (2019). Effect Evaluation of the Integration of Citizen Science Activities into Environmental Education Project Design: A Case Study of the Spring Swallow Survey Project. Cultures of Science, 2(2), 161-178. https://doi.org/10.1177/209660831900200207.

Nurwardani, P., Saksama H. Y., Winataputra, U. S., Budimansyah, D., Sapriya, Winarno, Mulyono, E., Prawatyani, S. J., Anwar, A. A., Evawany, Priyautama, F, \& Festanto, A. (2016). Pendidikan Kewarganegaraan untuk Perguruan Tinggi. Jakarta: Kemenristek Dikti.

Li, Y., Yang, S., Zhang, S., \& Zhang, W. (2019). Mobile Social Media Use Intention in Emergencies Among Gen Y in China: An Integrative Framework of Gratifications, Task-technology Fit, and Media DepeLindency. Telematics and Informatics, 42, 101244. https://doi.org/https://doi.org/10.1016/j.tele. 2019.101244.

Lilley, K., Barker, M., \& Harris, N. (2016). The Global Citizen Conceptualized: Accommodating Ambiguity. Journal of Studies in International Education, 21(1), 621. https://doi.org/10.1177/1028315316637354. 
Maryani, E., \& Syamsudin, H. (2009). Pengembangan Program Pembelajaran IPS untuk Meningkatkan Kompetensi Keterampilan Sosial. Jurnal Penelitian, Vol. 9 No., 1-15. http://jurnal.upi.edu/md/view/541/pengembangan-program-pembelajaran-ipsuntuk-meningkatkan-kompetensi-keterampilan-sosial.html.

Marzuki, \& Basariah. (2017). The Influence of Problem-Based Learning and Project Citizen Model in The Civic Education Learning on Student's Critical Thinking Ability and Self Disciplin. Cakrawala Pendidikan, XXXVI(3), 382-400. https://doi.org/10.21831/cp.v36i3.14675.

Miller, V. I. (2015). Value of Humanistic Grounds in the Field of Legal Education of Youth. Procedia - Social and Behavioral Sciences, 166, 427-433. https://doi.org/10.1016/j.sbspro.2014.12.548.

Milles, M. B. \& Huberman, A. M. (1992). Qualitatif Data Analysis: A Sourcebook of New Method. Jakarta: Penerbit Universitas Indonesia (UI-PRESS).

Moleong, L. J. (2011). Metodologi Penelitian Kualitatif Edisi Revisi. Bandung: PT. Remaja Rosdakarya.

Muijs, D., \& Reynolds, D. (2008). Effective Teaching. Yogyakarta: Pustaka Belajar.

Nederhand, J., \& Klijn, E. H. (2016). Stakeholder Involvement in Public-Private Partnerships: Its Influence on the Innovative Character of Projects and on Project Performance. Administration \& Society, 51(8), 1200-1226. https://doi. org/10.1177/0095399716684887.

Prabowo, S. L., \& Faridah., N. (2013). Perencanaan Pembelajaran Pada Bidang Studi, Bidang Studi Tematik, Muatan Lokal, Kecakapan Hidup, Bimbingan dan Konseling. Malang: UIN Maliki Press.

Ripat, J. D., Redmond, J. D., \& Grabowecky, B. R. (2010). The Winter Walkability Project: Occupational Therapists' Role in Promoting Citizen Engagement. Canadian Journal of Occupational Therapy, 77(1), 7-14. https://doi.org/10.2182/ cjot.2010.77.1.2.

Somantri, M. N., \& Winataputra, U. S. (2017). Disiplin Pendidikan Kewarganegaraan: Kultur Akademis dan Pedagogis. Bandung: Laboratorium PKn UPI.

Sopianingsih, P. (2016). Implementasi Model Project Citizen pada Pembelajaran Pkn sebagai Penguatan Karakter Siswa. Civicus, 20(2), 80-90. https://doi.org/10.21831/cp.v36i3.14675.

Trisiana, A., \& Wartoyo. (2016). Desain Pengembangan Model Pembelajaran Pendidikan Kewarganegaraanmelalui Addie Model untuk Meningkatkan Karakter Mahasiswa Di Universitas Slamet Riyadi Surakarta. Pkn Progresif: Jurnal Pemikiran dan Penelitian Kewarganegaraan, 11(1), 313-330. https://jurnal.fkip.uns.ac.id/index.php/progresif/article/view/9728.

Ulfah, N. (2017). Penerapan Pendekatan Active Learning pada Pendidikan Kewarganegaraan di Perguruan Tinggi sebagai Upaya Mengembangkan Kompetensi Kewarganegaraan. Paper Presented at Konferensi Nasional Kewarganegaraan III, Yogyakarta, Indonesia. http://eprints.uad.ac.id/id/eprint/9784.

Ulfah, N. S., \& Hamid, S. I. (2017). Model Project Citizen dalam Pembelajaran Pkn untuk Meningkatkan Keterampilan Berpikir Kritis Siswa. Antologi UPI, 5(1), 134-145.

Steden, R. V., Caem, B. V., \& Boutellier, H. (2011). The 'Hidden Strength' of Active Citizenship: The Involvement of local Residents in Public Safety Projects. 
Criminology \& Criminal Justice, 11(5), 433-450. https://doi.org/10.1177/ 1748895811414467.

Winarno. (2014). Pembelajaran Pendidikan Kewarganegaraan: Isi, Strategi, dan Penilaian. Jakarta: Bumi Aksara.

Winataputra, U. S., \& Budimansyah, D. (2007). Civic Education: Konteks, Landasan, Bahan Ajar, dan Kultur Kelas. Bandung: Prodi Pendidikan Kewarganegaraan, Pascasarjana UPI. 